\title{
Associated Farm and Farmer-Specific Factors for Climate-Smart Agriculture Adaptation in the Dry Zone: A Case from Vavuniya, Sri Lanka
}

\author{
V. Yogarajah ${ }^{1}$ and S.A. Weerasooriya ${ }^{2}$
}

\begin{abstract}
Climate-Smart Agriculture (CSA) technologies have been introduced to mitigate adverse climate change impacts. However, the adaptation of CSA technologies by farmers is relatively low in the dry zone of Sri Lanka. This study focuses on how farmers' adaptation behavior for CSA technologies varies with household characteristics, economic status, and farm characteristics. Data on 94 farmers were collected using a pre-tested questionnaire. A score was developed for each farmer on the adaptation of CSA technologies under 4 broad categories namely: water and energy-smart, nutrient and soil-smart, carbon and weather-smart, and knowledge and yieldsmart. A generalized linear model (GLM) was employed to identify the factors that influence farmers' adaptation and the level of adaptation. According to GLM results, income increases the adaptation of water and energy-smart technologies, while land ownership and managing livestock compared to labour decrease the adaptation. Adaptation of nutrient and soil-smart technologies were positively influenced by experience, and training while negatively influenced by labor use and managing livestock compared to crops. Adaptation of carbon and weather-smart technologies were positively influenced by income, cost of transport, higher education levels, managing both crop and livestock compared to only crop, and training while negatively influenced by the gender of the household head and household size, source of income, and land ownership. Knowledge and yield-smart technologies were positively influenced by income, level of education, and training while negatively influenced by only managing livestock compared to crops. Overall, the results suggest the importance of providing training and facilitating knowledge dissemination in addition to understanding the subtle issues that act as barriers to the adaptation of CSA technologies in dry zone farming.
\end{abstract}

Keywords: Climate-Smart Agriculture (CSA), CSA technologies, Factors influencing adaptation of CSA technologies

\footnotetext{
${ }^{1}$ Sri Lanka School of Agriculture, Vavuniya. vibeeshana02@gmail.com

2 Department of Agricultural Economics and Business Management, Faculty of Agriculture, University of Peradeniya. senal883@gmail.com
} 


\section{Introduction}

Climate change is emerging as a major threat to agriculture, food security, and the livelihood of millions of people in many places of the world (Branca et al., 2011; IPCC, 2014). According to many studies, subsistence agriculture remains one of the most vulnerable sectors to climate variability and change (Morton, 2007; Verchot et al., 2007; Lopez-Ridaura et al., 2018). In addition, climate change impact is predicted to be more severe in drier climates (Seo et al., 2005; Senaratne and Scarborough, 2011) and for smallholder farmers in particular (Kurukulasuriya and Ajwad, 2007; Belay et al., 2017; Azadi, Yazdanpanah, and Mahmoudi, 2019). In light of this, Food and Agriculture Organization (FAO) has recognized the importance of Climate-Smart Agriculture (CSA), for agriculture if it is to feed the world in a way that can protect sustainable rural development, as defined and presented at the Hague conference on agriculture, food security and climate change in 2010 (Mwongera et al., 2017). CSA is not defined as a set of practices or a wholly new type of agriculture. Rather, it is an approach that integrates different methods under a climate change umbrella. Alternatively, it is an approach for transforming and reorienting agricultural systems to support food security under the new realities of climate change (Lipper et al., 2014).

In the face of climate change, CSA gives farmers tools and a pathway to make their operations and livelihoods more productive and resilient, as well as reduces adverse impacts on the climate (Steenwerth et al., 2014). CSA technologies are important to meet climatic challenges by increasing resilience to weather extremes, adapting to climate change and decreasing agriculture's greenhouse gas emissions, and also supporting sustainable food security and agricultural productivity (McCarthy, Lipper and Branca, 2011). Some common examples of CSA technologies are drip irrigation, sprinkler irrigation, raised beds, composting, soil management, drainage management, residue management, fertilizer management, crop insurance, land use planning, cover crops, mulching, livestock management, agroforestry, and fodder management. Suitable CSA technologies will differ in terms of application and benefits due to several factors such as region, ecosystem, climate, crops, farmers' perceptions, and farmer's adaptation behavior (Khatri-Chhetri et al., 2017). In developing countries, for smallholder farmers, adopting CSA technologies offers opportunities for greater food security and increased income together with greater resilience (Lopez-Ridaura et al., 2018). Yet, the adaptation of CSA technologies is slow and of limited capacity among smallholder farmers due to various socio-economic, demographic, and policy trends (Morton, 2007; Kpadonou et al., 2017). 
Sri Lankan agriculture has already felt the effect of adverse weather events and climate changes (Truelove, Carrico, and Thabrew, 2015). With population growth, the expansion of arable land will likely continue in many regions (Wickremasinghe, 2006). Climate change will continue to impact the agricultural sector in general, and adaptation of CSA technologies to overcome losses due to climatic variations is of great importance in a Sri Lankan context where traditional and modern climate adaptation strategies co-exist (World Bank CIAT, 2015). In the past, traditional farmers have intelligently used genetic diversity to develop crop and livestock varieties to counter environmental stresses. According to climate predictions, Sri Lanka's wet areas are becoming wetter, while the dry areas are becoming drier, affecting the agriculture activities in both dry and wet zones (Marambe et al., 2015). However, with increased temperature and reduced rainfalls, and sudden climate vagaries, agriculture in the dry zone is adversely impacted more so than in other areas (Thadshayini, Nilanthi, and Ginigaddara, 2020). As a result, CSA technologies have become more important than ever and need more attention.

Realizing the importance of climate change adaptation, the Sri Lankan government has taken several initiatives at the policy level to address the concerns of climate change. First and foremost, Sri Lanka was among the first 50 countries to approve the United Nations Framework Convention on Climate Change (UNFCCC) in 1993. In addition, it became a signatory to the Montreal and Kyoto Protocols in 2002 (World Bank CIAT, 2015). Climate change issues are anchored in different sectorial policies domestically where these policies attempt to address the adaptive and mitigation strategies. Main national policies that concern CSA includes The National Environment Policy (NEP), The National Climate Change Policy (NCCP), The National Climate Change Adaptation Strategy (NCCAS), the action plan for Haritha Lanka program, and the roadmap for disaster risk management (World Bank CIAT, 2015). Additionally, several sectoral directives provide a guide for the adaptation of CSA. These directives include the National Agriculture Policy, National Agricultural Research Policy, National Livestock Development Policy, and the National Fisheries and Aquatic Resource Policy (World Bank CIAT, 2015). Prasannath (2015) argues that little effort has been made to mainstream climate change adaptation into national development policies until the NCCAS was formulated in 2010.

The majority of the farm families in the dry zone of Sri Lanka depend directly on paddy and other field crop cultivation for their living (Wickremasinghe, 2006). In addition, dry zone farming is often 
associated with high poverty levels, marginal land, and low water availability, and hence, it could be difficult for these farmers to adopt CSA technologies to mitigate climate change impacts stemming from changing rainfall patterns, more frequent droughts, high temperatures, and pests and diseases. Given this difficulty in adapting, applying CSA technologies in the dry zone would require a great deal more attention, priority, and support from policymakers. There is an urgent need to implement CSA technologies to help smallholder farmers adapt to changing climate in the dry zone. There are many factors identified in the literature that influence the extent of the adaptation of CSA technologies (Pagliacci et al., 2020). It is important to identify these factors in a Sri Lankan dry zone setting as it provides insight into better policymaking. Therefore, this study mainly concerns how farmers' adaptation behavior of CSA technologies varies with farmers' household characteristics, economic status, and farm characteristics. Within this milieu, the overall objective of this study is to analyze the determinants of farmers' adaptation behavior of CSA technologies in the District of Vavuniya in Sri Lanka.

In Vavuniya, most of the farm families are characterized as smallholders who are engaged in agriculture and agriculture-related activities. Recent surveys indicated that $38 \%$ of the total land is engaged in agriculture and $47 \%$ of the land is under forest. The most cultivated crops are cereals, pulses, oilseeds, root and tuber crops, low country vegetables, upcountry vegetables, and minor export crops. Livestock is significant and popular in the district which includes rearing of cattle, buffaloes, and poultry farming are the main forms of livestock farming (Wickremasinghe, 2006). Vavuniya as a study area is appropriate as it is emblematic of most of the problems faced by dry zone agriculture in Sri Lanka among smallholder farmers.

The remainder of this article is as follows. In the next section, a literature review provides a preview of identifying components of CSA technologies and their measurement and identifying factors affecting the adaptation of CSA technologies among smallholder farmers in a developing country context. The subsequent sections discuss the data collection, method and results, and discussion. Final section deals with conclusions, and implications of the results. 


\section{Literature Review}

In this section, an attempt is made to look into the CSA technologies, classification and adaptation behavior, and factors affecting the adaptation of CSA technologies.

\section{CSA Technologies, Classification and Adaptation Behavior}

Smallholder farmers are particularly vulnerable to the changes in the climate that reduce productivity and affect their weatherdependent livelihood systems negatively (Khatri-Chhetri et al., 2017). To overcome these threats, farmers have to adapt to climate changes. Some adaptation strategies proposed are using scarce water resources more efficiently, mitigation and adaptation, building flood defenses, developing drought and disease tolerant crop varieties, choosing tree species and forestry practices, integrated pest management, improve the policies, developing infrastructures, and adapting CSA technologies (Mccarthy, Lipper, and Branca, 2011). Within the realm of such adaptation strategies, CSA has garnered much interest due to its implications on development and food security. CSA technologies are defined as a set of adaptation options that sustainably increase productivity, enhance resilience to climatic stresses, and reduce greenhouse gas emissions (FAO, 2010). It is built on three pillars i.e., increasing productivity and incomes, enhancing the resilience of livelihoods and ecosystems, and reducing and removing greenhouse gas emissions from the atmosphere (FAO, 2014).

CSA is an approach for developing agricultural strategies to secure sustainable food security under climate change. It provides the means to help stakeholders from local to national and international levels identify agricultural strategies suitable to their local conditions. The adaptation behavior of CSA technologies aid in reducing the vulnerability of resource-poor farmers to some extent by diversifying their income-generating practices (Qui, 2016). Therefore, among the adaptation strategies, CSA technologies are the most appropriate strategy for smallholder farmers in developing countries (UNDP, 2007).

It is noteworthy to have a well-defined classification of CSA technologies before understanding their adaptation by smallholder farmers. Based on several studies, this study employed a classification that classified technologies supporting at least one or more of the pillars of CSA (Aggarwal, Zougmore and Kinyangi, 2013; Dunnett and Shrisath, 2013; Sapkota et al., 2014; Sapkota et al., 2015; Khatri-Chhetri et al., 2017; Mwongera et al., 2017). According to the classification, 
CSA technologies have been broadly categorized as water-smart, energy-smart, nutrient-smart, carbon-smart, weather-smart, and knowledge-smart technologies (Aggarwal, Zougmore and Kinyangi, 2013; Khatri-Chhetri et al., 2017).

Adaptation strategies for climate change should enhance and build on health and functional ecosystems, these strategies provide several benefits and services on which agricultural production systems and rural livelihoods depend (Sheinkman et al., 2015). This adaptation can occur in various dimensions. Adaptation behaviors could be viewed as a community-based adaptation approach and ecosystem-based adaptation approach (Khatri-Chhetri et al., 2017). On the other hand, they can be viewed as incremental or transformational (Koji, 2016) where both incremental and transformational adaptation strategies require integration, policy planning, and resource mobilization. It is apparent that there are various dimensions in which such adaptation can take place. Encompassing all this, there is a need to take action to hasten the adaptation to reduce vulnerabilities of smallholder farming systems to adverse climate change risks and assess and implement the strategies for enhancing resilience.

\section{Factors Influencing the Adaptation Behavior of CSA Technologies}

The decision about which CSA technology to adopt to overcome climatic impacts is the farmers' choice to make as per the needs of his or her farm. Some characteristic features of effective adaptation efforts in most of the countries include community participation, use of indigenous knowledge and practices, development of local technologies, stakeholder networking, and combination of the conventional technological innovation process with the knowledge of farmers (Sain et al., 2017). If a policymaker or a planner decide on adaptation strategies, two key concerns arise related to decisions around investigating and promoting the adaptation of agricultural practices such as will the technologies be profitable for individual farmers, ensuring more likelihood of long term adaptation, and will the technologies provide public benefits (Mwongera et al., 2017).

Some key factors such as farmers' household characteristics, income status, farm characteristics, climatic variations, labor available to carry out agronomic practices, information availability, initial capital for the establishment, available space in small land holdings, availability of planting materials, and availability of alternative methods influence on adaptation of CSA technologies (Lopez-Ridaura et al., 2018). Adaptation of new technologies, innovations, or practices takes place 
within a socio-cultural environment and requires key inputs such as labor, finance, production, and social capital. Better organization and allocation of the various forms of inputs would enhance efficiency important for the adaptation and diffusion of interventions to achieve the desired impact in the farming system (Nyasimi et al., 2017). In addition, demand and supply-side drivers also may act as barriers to the adaptation of CSA technologies (Long, Blok and Connix, 2016).

There are some attributes of farmers that directly influence adaptation measures such as land ownership, type of cultivation method, and land distance with water resources. The factors that influence farmers' adaptation behavior are according to the farmers' internal factors such as characteristics, knowledge, perceptions, and external forces such as economy, policy, environmental, and technology (Neufeldt et al., 2013). In addition, influence on adaptation behavior of farmers such as household heads educational attainment, farming experience, land size, perception of climate change impacts, knowledge and skills, the stability of farm productivity, soil protection strategies, income, access to the information, access to the market, extension services, crop diversity, livestock production, institutional, policy and technical support are found to be the factors influencing the adaptation behavior of CSA technologies (Middelberg, 2013). In a Sri Lankan context, insufficient resources, limited marketing options have been highlighted as reasons for poor adaptation although these impacts have never been quantified (World Bank CIAT, 2015).

All in all, there is a dearth of studies that have looked at the adaptation of CSA among smallholder farmers, especially in the dry zone of Sri Lanka. Such a study contributes to the literature by enabling informed policymaking. Thereby, this study attempts to fill this research gap by quantifying this adaptation using an econometric model using data from a dry zone context in Sri Lanka.

\section{Methodology}

\section{Data Collection}

The study used primary data from a selected sample of smallholder farmers in the District of Vavuniya for the year 2019. A multistage sampling approach was used. Among the eight Agriculture Production Centers (APCs) in Vavuniya, two were randomly selected. Thereafter, from each selected APC, two villages were randomly 
selected $^{3}$. From each selected APC, a list of registered farmers was obtained. From the list, 94 farmers were randomly selected (i.e., from each village $22,25,24$, and 23 smallholder farmers were randomly selected based on the number of registered farmers at the selected APCs). A pre-tested questionnaire was used to collect data from the sample. CSA technologies were categorized into water and energysmart, nutrient and soil-smart, carbon and weather-smart, and knowledge and yield-smart technologies. Under each category, a set of CSA technologies were selected ${ }^{4}$. For each CSA technology, a binary question was asked where a score of 1 was given if the farmer said "Yes" and 0 if the farmer said "No". Before getting the answer, the farmers were given a detailed explanation of what each technology was. These binary scores were then used to compile a composite score for the 4 broad categories by summing the responses. The entire list of CSA technologies under the 4 broad categories is given in Table 1 along with the reason for their use. As shown in Table 1, there are 10 listed underwater and energy-smart, 9 listed under Nutrient and soil-smart, 9 listed under carbon and weather-smart, and 11 listed under knowledge and yield smart-technologies respectively. Therefore, the maximum scores that can be obtained for water and energy, nutrient and soil, carbon and weather, and knowledge and yield smart technologies were $10,9,9$, and 11 respectively while the minimum value was 0 .

\section{Table 1: Classification of CSA technologies}

CSA technology Potential reasons for its adaptation

(1) Water \& Energy smart

(i) Rainwater harvesting

(ii) Drip irrigation

(iii) Sprinkler irrigation

(iv) Furrow irrigated bed planting

(v) Raised bed
Interventions that improve water use and energy use efficiency

Collection of rainwater not allowing to run off and use for agriculture and other purposes on-site

Application of water directly to the root zone of crops and minimize water loss

Efficient water management by reducing losses

Offers more effective control over-irrigation and drainage as well as rainwater management (also improves nutrient use efficiency).

Reduce soil erosion and better water use efficiency

\footnotetext{
${ }^{3}$ Nedunkerny, Kulavisuddan, Paranthan, and Mathiyamadu.

${ }^{4}$ Any technology that supported at least one of the three pillars i.e., productivity, resilience and mitigation in agriculture under climate change and variability were considered as a CSA technology. These were selected based on Aggarwal, Zougmore and Kinyangi (2013) and Khatri-Chhetri et al. (2017).
} 
(vi) Drainage management

(vii) Cover crops

(viii) Direct seeded rice

(ix) Zero/minimum tillage

(x) Residue management

(2) Nutrient \& Soil smart

(i) Green manuring

(ii) Site-specific integrated nutrient management

(iii) Intercropping with legumes

(iv) Crop rotation

(v) Organic fertilizers

(vi) Composting

(vii) Terraces

(viii) Vegetative strips

(ix) Mulching

(3) Carbon \& Weather smart

(i) Agroforestry
Removal of excess water through water control structures

Reduces evaporation loss of soil water (also adds nutrients into the soil)

Increase water and energy efficiencies

Reduce the amount of energy use in land preparation

Improve soil and water management practices and reduction of energy loss from the farm-site

Interventions that improve nutrient use efficiency and overall quality of soil

Cultivation of legumes in a cropping system. This practice improves nitrogen supply and soil quality

Optimum supply of soil nutrients over time and space matching to the requirements of crops with the right product, rate, time, and place

Cultivation of legumes with other main crops in alternate rows or mixed. This practice improves nitrogen supply and soil quality

Improve soil fertility and control weeds, pests, and diseases

On-farm production and improve the health and quality of soil

Supplies beneficial microorganisms to the soil, and improves overall soil health and quality

Conservation of soil and water and reduce soil erosion

Suppress weeds and reduce soil erosion

Increase soil moisture retention, reduce soil compaction, and attract earthworms

Interventions that reduce greenhouse gas emissions and interventions that provide services related to income security and weather advisories to farmers

Promote carbon sequestration including sustainable land use management 
(ii) Concentrate feeding Reduces nutrient losses and livestock requires a for livestock low amount of feed

(iii) Fodder management Promote carbon sequestration including sustainable land use management

(iv) Integrated pest Reduces use of chemicals management

(v) No-tillage

Improved soil conditions due to the decomposition of plant residues in situ

(vi) Biogas production

(vii) Climate-smart housing for livestock

Reduce the greenhouse gas emissions and residue management

Protection of livestock from extreme climatic events (e.g., heat stresses)

(viii) Weather-based Crop Climate information-based value-added agroAgro-advisory

(ix) Crop insurance advisories to the farmers

Crop-specific insurance to compensate income loss due to vagaries of weather

(4) Knowledge \& Yield smart

Interventions that use a combination of science and local knowledge to improve productivity

(i) Contingent crop planning

Climatic risk management plan to cope with major weather-related contingencies like drought, flood, heat/cold stresses during the crop season

(ii) Improved crop varieties

crop Crop varieties that are tolerant to drought, flood, and heat stresses

(iii) Seed \& fodder banks Conservation of seeds of crops and fodders to manage climatic risks

(iv) Gender empowerment Increase the female participation and increase the knowledge pool and contribute towards higher productivity

(v) Capacity development

Reduce the dependency on others and improve sustainable agriculture and rural development

(vi) Land use planning Enhance the efficient use of resources with minimal impacts on the yield

(vii) Extension \& technical assistance

Provide advice to farmers to overcome extreme climatic variations to increase productivity and improve rural livelihoods

(viii) Tolerant varieties To overcome diseases and adverse weather conditions and get better yield

(ix) Hybrid crop varieties

(x) Drought \& disease tolerant crops

To get better yield and disease resistance

Overcome impacts due to drought and disease infection and get better yield

(xi) Salinity monitoring To increase the soil productivity and enhance the growth of crops

Based on Aggarwal, Zougmore and Kinyangi (2013); Khatri-Chhetri et al. (2017). 
Also, farmers' household information, economic status, farm characteristics, familiarization about CSA technologies, and current practices among the CSA technologies in the farm were obtained. The descriptive statistics of the collected variables are given in Table 2.

Table 2: Descriptive statistics of the data

\begin{tabular}{|c|c|c|c|c|c|}
\hline Variable & Definition & Mean & Max & Min & SD \\
\hline $\begin{array}{l}\text { Household } \\
\text { type }\end{array}$ & $\begin{array}{l}\text { Head of the household } \\
\text { (Dummy: } \quad 1=\text { female, } \\
0=\text { male) }\end{array}$ & 0.14 & 1 & 0 & 0.35 \\
\hline $\begin{array}{l}\text { Household } \\
\text { size }\end{array}$ & $\begin{array}{l}\text { Number of individuals } \\
\text { in the household }\end{array}$ & 3.33 & 7 & 1 & 1.36 \\
\hline $\begin{array}{l}\text { Cost of } \\
\text { transport/year }\end{array}$ & $\begin{array}{l}\text { Annual expenditure to } \\
\text { access } \\
\text { (LKR/year) }\end{array}$ & 27,511 & 96,000 & 0 & 24,768 \\
\hline $\begin{array}{l}\text { Agricultural } \\
\text { loans }\end{array}$ & $\begin{array}{l}\text { Farmers who obtain } \\
\text { loans for farming } \\
\text { (Dummy: } 1=\text { yes, } 0=\text { no) }\end{array}$ & 0.41 & 1 & 0 & 0.49 \\
\hline Income/year & $\begin{array}{l}\text { Annual household } \\
\text { income (LKR/year) }\end{array}$ & 556,983 & $2,400,000$ & 480 & 456,008 \\
\hline $\begin{array}{l}\text { Source of } \\
\text { income }\end{array}$ & $\begin{array}{l}\text { On-farm, or on-farm } \\
\text { and off-farm both } \\
\text { (Dummy: } 1=\text { on-farm } \\
\text { and off-farm, } 0=\text { on- } \\
\text { farm) }\end{array}$ & 0.37 & 1 & 0 & 0.47 \\
\hline $\begin{array}{l}\text { Government } \\
\text { support }\end{array}$ & $\begin{array}{lr}\text { Received } & \text { subsidies, } \\
\text { extension } & \text { assistance } \\
\text { and/or } & \text { financial } \\
\text { assistance } & \text { (Dummy: } \\
1=\text { yes, } 0=\text { no) } & \end{array}$ & 0.11 & 1 & 0 & 0.31 \\
\hline Land size & $\begin{array}{l}\text { Extent of the land } \\
\text { (acres) }\end{array}$ & 4.75 & 15 & 0.25 & 3.13 \\
\hline $\begin{array}{l}\text { Land } \\
\text { ownership }\end{array}$ & $\begin{array}{l}\text { Leased/Traditional land } \\
\text { (Dummy: 1=leased, } \\
0=\text { traditional) }\end{array}$ & 0.043 & 1 & 0 & 0.20 \\
\hline $\begin{array}{l}\text { Management } \\
\text { practices }\end{array}$ & $\begin{array}{l}\text { Only crops, only } \\
\text { livestock, both crops } \\
\text { and } \quad \text { livestock } \\
\text { (Categorical: } 0=\text { crop, } \\
1=\text { livestock, } 2=\text { both) }\end{array}$ & 1.63 & 2 & 0 & 0.78 \\
\hline
\end{tabular}


Table 2 contd...: Descriptive statistics of the data

\begin{tabular}{|c|c|c|c|c|c|}
\hline Variable & Definition & Mean & Max & Min & $\mathrm{SD}$ \\
\hline Experience & Years of doing farming & 24.01 & 55 & 3 & 12.45 \\
\hline $\begin{array}{l}\text { Level of } \\
\text { education }\end{array}$ & $\begin{array}{l}\text { No education, primary, } \\
\text { secondary, tertiary } \\
\text { (Categorical: } 1=\text { no } \\
\text { education, 2=primary, } \\
\text { 3=secondary, } \\
\text { 4=tertiary) }\end{array}$ & 1.51 & 4 & 1 & 0.67 \\
\hline $\begin{array}{l}\text { Knowledge } \\
\text { of climate } \\
\text { changes }\end{array}$ & $\begin{array}{l}\text { Awareness of climate } \\
\text { changes (Dummy: } \\
1=\text { yes, } 0=\text { no) }\end{array}$ & 1 & 1 & 1 & 0 \\
\hline Labor use & Labor days & 0.74 & 1 & 0 & 0.44 \\
\hline $\begin{array}{l}\text { Total CSA } \\
\text { technologies }\end{array}$ & $\begin{array}{l}\text { Overall adaptation of } \\
\text { CSA technologies }\end{array}$ & 28.36 & 37 & 6 & 5.41 \\
\hline $\begin{array}{l}\text { Water and } \\
\text { energy smart }\end{array}$ & $\begin{array}{l}\text { Technologies related to } \\
\text { water and energy } \\
\text { conservation }\end{array}$ & 6.57 & 10 & 0 & 1.64 \\
\hline $\begin{array}{l}\text { Nutrient and } \\
\text { soil smart }\end{array}$ & $\begin{array}{l}\text { Interventions that } \\
\text { improve nutrient use } \\
\text { efficiency and overall } \\
\text { quality of soil }\end{array}$ & 6.49 & 8 & 0 & 1.63 \\
\hline $\begin{array}{l}\text { Carbon and } \\
\text { weather } \\
\text { smart }\end{array}$ & $\begin{array}{l}\text { Interventions that } \\
\text { reduce greenhouse gas } \\
\text { emissions and } \\
\text { interventions that } \\
\text { provide services related } \\
\text { to income security and } \\
\text { weather advisories to } \\
\text { farmers }\end{array}$ & 5.56 & 9 & 2 & 1.87 \\
\hline $\begin{array}{l}\text { Knowledge } \\
\text { and yield } \\
\text { smart }\end{array}$ & $\begin{array}{l}\text { Interventions that use a } \\
\text { combination of science } \\
\text { and local knowledge to } \\
\text { improve productivity }\end{array}$ & 9.73 & 11 & 3 & 1.76 \\
\hline
\end{tabular}




\section{Econometric Analysis}

In this study, an econometric model was used to probe into factors affecting farmers' adaptation and the factors influencing the level of adaptation of different CSA technologies. The following model was used;

$$
Y=\beta_{0}+\beta_{i} X_{i}+U_{i}
$$

Where, $\boldsymbol{Y}$ is the dependent variable which is defined by, farmers' adaptation behavior score over a set of CSA technologies. $\boldsymbol{X}_{\boldsymbol{i}}$ is a set of independent variables which included: (i) farmers' household characteristics (gender of the household head, household size, and education level of the household head), (ii) farmers' economic status (source of income, annual income, government support, and whether an agricultural loan is taken), and (iii) farm characteristics (land size, land ownership, type of practice, labor use, cost of transporting produced, training exposure, and experience). Since the dependent variable was not continuous and lower and upper bounded, Ordinary Least Squares (OLS) regression will not yield appropriate estimates. In this study, a Generalized Linear Model (GLM) proposed by Papke and Wooldridge (1996) was used in the estimation. The quasi-likelihood method they propose is fully robust and relatively efficient under the GLM assumption and performs better when the dependent variable is a count, and nonnegative. The residual analysis yielded that the error is normally distributed and robust standard errors were used to counter heteroskedasticity.

\section{Results and Discussion}

Table 4 depicts the results obtained for the GLM regression. Four separate regressions were done for the defined categories of CSA technologies. As shown in Table 4, when the household was headed by a female, adaptation of carbon and weather-smart technologies have decreased compared to a household headed by a male $\left(-0.371^{* * *}\right)$. One of the plausible reasons might be that carbon and weather-smart technologies are labor-intensive (Khatri-Chhetri et al., 2017). Household size and the having on-farm and off-farm income sources compared to only on-farm income influence adaptation of carbon and weather-smart technologies negatively $\left(-0.081^{* *}\right.$ and $\left.-0.427^{* * *}\right)$ while positively $\left(0.225^{*}\right.$ and $\left.0.683^{*}\right)$ influencing the adaptation of knowledge and yield-smart technologies. This implied that farmers tend to funnel their resources to adapt knowledge and yield-smart technologies before carbon and weather-smart technologies. The cost of transportation of 
produce has a statistically significant yet small positive impact on the adaptation of carbon and weather and knowledge and yield-smart technologies $\left(0.001^{* * *}\right)$. This may be attributed to the direct impact of cost on the yield as production theory suggests. Annual income shows a statistically significant impact on the adaptation of water and energy and carbon and weather-smart technologies. However, income has no impact on the adaptation of nutrient and soil-smart and knowledge and yield-smart CSA technologies. This may be attributed to fewer resources required for nutrient and soil-smart and knowledge and yieldsmart technologies (Khatri-Chhetri et al., 2017). Compared to traditional land, leased land showed less adaptation towards water and energysmart and carbon and weather-smart technologies $\left(-0.485^{* * *}\right.$ and $\left.0.411^{* * *}\right)$. The low adaptation of these technologies by leased/rented lands can be attributed to a lack of motivation due to a lack of proper rights to the land. In addition, this can be further explained by the risk averseness of the farmers (Tong et al., 2019). According to the results, managing only livestock compared to crops significantly reduces adaptation in all categories except carbon and weather-smart technologies. Farmers who manage only livestock do not want to implement water and energy-smart, nutrient and soil-smart, and knowledge and yield-smart technologies as these technologies are more related to crops. Therefore, if only livestock is practiced, it decreases the adaptation behavior of these three technologies significantly. However, when both crop and livestock are done together, the adaptation of carbon and weather-smart technologies seems to increase compared to only when crops are managed $\left(1.332^{* * *}\right)$. This may attribute to the fact that carbon and weather-smart technologies include many interventions that complement both crops and livestock. The experience was only a significant driver for nutrient and soil-smart technologies $\left(0.017^{* * *}\right)$. Compared to other technologies, most of the nutrient and soil-smart technologies are traditional technologies. Therefore, this increase in adaptation of nutrient and soil-smart technologies can be in part explained by the increase in farmers' experience. Compared to receiving no formal education, having tertiary education positively influenced the adaptation of all technologies excluding nutrient and soil-smart technologies. Other than that, the adaptation of carbon and weathersmart technologies was influenced by having primary, secondary, and tertiary education compared to receiving no formal education. This indicates that as farmers receive education, they tend to adapt more CSA technologies. Whether or not farmers received training was the only variable that positively influenced the adaptation of all CSA technologies. This highlighted the importance of providing training for farmers if the higher adaptation of CSA technologies is desired. An increase in labor use was associated negatively $\left(-0.002^{* * *}\right)$ only with 
nutrient and soil-smart technologies due to its less labor intensiveness compared to other technologies. Therefore, increased labor indicated moving away from nutrition and soil-smart technologies. Interestingly, government support and land size did not have a significant impact on the adaptation of any of the CSA technologies.

\section{Table 4: Parameter estimates of generalized linear model}

\begin{tabular}{|c|c|c|c|c|}
\hline Variable & $\begin{array}{c}\text { Water \& } \\
\text { energy } \\
\text { smart }\end{array}$ & $\begin{array}{l}\text { Nutrient \& } \\
\text { soil smart }\end{array}$ & $\begin{array}{c}\text { Carbon \& } \\
\text { weather } \\
\text { smart }\end{array}$ & $\begin{array}{c}\text { Knowledge } \\
\& \text { yield } \\
\text { smart }\end{array}$ \\
\hline \multirow{2}{*}{$\begin{array}{l}\text { Gender of the } \mathrm{HH} \\
\text { head }\end{array}$} & -0.261 & 0.158 & $-0.371 * * *$ & 0.287 \\
\hline & $(0.162)$ & $(0.146)$ & $(0.118)$ & $(0.400)$ \\
\hline \multirow[t]{2}{*}{ HH size } & -0.033 & 0.016 & $-0.081 * *$ & $0.225^{*}$ \\
\hline & $(0.054)$ & $(0.043)$ & $(0.038)$ & $(0.121)$ \\
\hline \multirow[t]{2}{*}{ Cost of transport } & $<0.001$ & $<0.001$ & $<0.001 *$ & $<0.001 * * *$ \\
\hline & $(<0.001)$ & $(<0.001)$ & $(<0.001)$ & $(<0.001)$ \\
\hline \multirow[t]{2}{*}{ Obtained agri-loans } & -0.053 & 0.140 & -0.153 & -0.298 \\
\hline & $(0.107)$ & $(0.131)$ & $(0.105)$ & $(0.277)$ \\
\hline \multirow[t]{2}{*}{ Annual income } & $<0.001 * * *$ & $<0.001$ & $<0.001 * * *$ & $<0.001$ \\
\hline & $(<0.001)$ & $(<0.001)$ & $(<0.001)$ & $(<0.001)$ \\
\hline \multirow[t]{2}{*}{ Source of income } & -0.216 & -0.034 & $-0.427 * * *$ & $0.683^{*}$ \\
\hline & $(0.147)$ & $(0.157)$ & $(0.154)$ & $(0.370)$ \\
\hline \multirow[t]{2}{*}{ Government support } & -0.140 & -0.020 & -0.213 & -0.432 \\
\hline & $(0.184)$ & $(0.277)$ & $(0.162)$ & $(0.460)$ \\
\hline \multirow{2}{*}{ Land size } & 0.006 & -0.004 & 0.031 & -0.027 \\
\hline & $(0.024)$ & $(0.023)$ & $(0.025)$ & $(0.078)$ \\
\hline \multirow[t]{2}{*}{ Land ownership } & $-0.485 * * *$ & -0.290 & $-0.411 * *$ & 0.235 \\
\hline & $(0.179)$ & $(0.688)$ & $(0.181)$ & $(0.694)$ \\
\hline \multicolumn{5}{|l|}{ Management practice } \\
\hline \multirow[t]{2}{*}{ Livestock } & $-18.32 * * *$ & $-21.85 * * *$ & -0.128 & $-2.935 * * *$ \\
\hline & $(1.029)$ & (1.039) & $(0.138)$ & $(0.453)$ \\
\hline \multirow[t]{2}{*}{ Crop and livestock } & -0.020 & 0.383 & $1.332 * * *$ & 0.442 \\
\hline & $(0.180)$ & $(0.277)$ & $(0.141)$ & $(0.420)$ \\
\hline \multirow[t]{2}{*}{ Experience } & -0.006 & $0.017 * * *$ & 0.000 & 0.002 \\
\hline & $(0.005)$ & $(0.006)$ & $(0.004)$ & $(0.014)$ \\
\hline \multicolumn{5}{|l|}{ Education level } \\
\hline \multirow[t]{2}{*}{ Primary } & -0.039 & -0.037 & $0.273^{*}$ & 0.046 \\
\hline & $(0.132)$ & $(0.130)$ & $(0.144)$ & $(0.348)$ \\
\hline \multirow[t]{2}{*}{ Secondary } & 0.282 & -0.970 & $0.792 * *$ & -1.122 \\
\hline & $(0.427)$ & $(0.678)$ & $(0.332)$ & (1.038) \\
\hline \multirow[t]{2}{*}{ Tertiary } & $1.995 * * *$ & 0.369 & $1.328 * * *$ & $11.532 * * *$ \\
\hline & $(0.757)$ & $(0.264)$ & $(0.240)$ & (1.208) \\
\hline \multirow[t]{2}{*}{ Got training } & $0.420 * * *$ & $0.454 * * *$ & $0.216^{*}$ & $0.836 * *$ \\
\hline & $(0.124)$ & $(0.147)$ & $(0.115)$ & $(0.341)$ \\
\hline \multirow{2}{*}{ Labor days } & -0.001 & $-0.002 * *$ & 0.000 & 0.007 \\
\hline & $(0.000)$ & $(0.001)$ & $(0.000)$ & $(0.005)$ \\
\hline$N$ & 94 & 94 & 94 & 94 \\
\hline
\end{tabular}


The findings of this study are in sync with previous studies (Long et al., 2016; Khatri-Chhetri et al., 2017; Mwongera et al., 2017; Wekesa, Ayuya and Lagat, 2018; Imran et al., 2018; Saker et al., 2019; Tong, 2019). It is important to note that several important drivers have emerged with the results in Table 4. First, it was seen that providing training was an important driver of increasing adaptation of CSA technologies. Second, the level of education also seems to be influencing factors for adopting more CSA technologies. Both these collectively highlight the importance of training, knowledge dissemination, and information availability (McCarthy, Lipper and Branca, 2011; Nyasimi et al., 2017; Franzel, Kiptot, and Degrande, 2019; Jellason, Conway, and Baines, 2021).

\section{Conclusions}

Farmers in the dry zone of Sri Lanka have experienced the adverse effects of changing climatic conditions over a while. This has been exacerbated with longer dry spells and declining precipitation. As a way out, the adaptation of CSA technologies has been brought into the limelight through state-level policies geared towards combating climate change. However, there are concerns about the slow adaptation of such technologies in a Sri Lankan context. Farmer's adaptation of CSA technologies is to overcome adverse climate change impacts. This adaptation behavior is influenced by several factors, which created incentives or barriers for the uptake of specific practices. In this study, the District of Vavuniya, which is emblematic of most of the dry zone agricultural issues, was used to see the factors influencing the adaptation of CSA technologies. Following a review of literature, the CSA technologies were categorized into 4 broad categories namely water and energy, nutrient and soil, carbon and weather, and knowledge and yieldsmart where each category contained several questions which elicited the use of a particular CSA technology. From the review of literature, several determinants that potentially might influence the adaptation of the said CSA technologies were selected. A GLM model was used to determine the impact of the factors on the levels of adaptation of CSA technologies. The results show that, adaptation behavior and the level of adaptation are influenced by income and whether or not training was provided. In addition, education level, land ownership, management practice, experience seems to have an impact among other variables. Broadly, farm household characteristics, economic status, and farmspecific characteristics have impacted the adaptation and the level of adaptation of CSA technologies. 
The findings of this study highlight several important factors. The analysis provides useful information for policymakers to come up with better policy interventions to counter the challenges of climate change. Such policy interventions would include providing training and awareness and information availability and dissemination about CSA technologies. Therefore, planning and implementing programs to increase awareness and also provide training through government agencies would boost farmers' use of CSA technologies by facilitating dissemination.

Despite its feasibility, this study is not devoid of several limitations. First, a limited sample was used in the study. A larger sample will probably provide a better picture. Second, the study was only limited to the District of Vavuniya. While it is representative of the issues present in dry zone agriculture, further studies should be done in other dry zone areas to counter the heterogeneity stemming due to farm and off-farm factors. Third, the analysis was only limited to a particular year. Data stemming from several years and panel data econometric techniques would provide more robust results. Fourth, the study only contained data from the dry zone. It is also noteworthy to incorporate information from the wet zone and intermediate zones since they too are facing adverse effects of climate change. Thereby, policymakers will find it useful to look into the aspects of the adaptation behavior of farmers in the wet zone and intermediate zone. Fifth is the complementary nature of the CSA technologies. While this study used the technologies listed under the classification, it did not address the possible complementarity between these technologies. Future studies in this area should try to incorporate this aspect.

In light of these limitations, the study proposes several recommendations for future studies. Analysis should be done for disaggregated CSA technologies due to their heterogeneity. In addition, farmers' adaptation behavior on CSA technologies should be investigated in other agro-ecological zones particularly focusing on upcountry vegetables, paddy, and plantation crops, etc. In addition, promoting climate change awareness, providing training, increase the level of education, different promotion programs for the farmers who are in different stages of adaptation can be thought of as potential interventions. Given that this study has found the importance of training programs, future research can focus on studying the effectiveness of such programs. All in all, this study sheds light on an important issue that might help Sri Lanka overcome the rippling effect of climate change on agriculture in the long run. 


\section{References}

Aggarwal, P., Zougmore, R., \& Kinyangi, J. (2013). Climate-smart villages: A community approach to sustainable agricultural development. The Consultative Group for International Agricultural Research's (CGIAR) Research Program on Climate Change, Agriculture, and Food Security (CCAFS), Copenhagen, Denmark.

Azadi, Y., Yazdanpanah, M., \& Mahmoudi, H. (2019). Understanding smallholder farmers' adaptation behaviors through climate change beliefs, risk perception, trust, and psychological distance: Evidence from wheat growers in Iran. Journal of Environmental Management, 250, 109456.

Belay, A., Recha, J. W., Woldeamanuel, T., \& Morton, J. F. (2017). Smallholder farmers' adaptation to climate change and determinants of their adaptation decisions in the Central Rift Valley of Ethiopia. Agriculture \& Food Security, 6(1), 1-13.

Branca, G., McCarthy, N., Lipper, L., \& Jolejole, M. C. (2011). Climatesmart agriculture: A synthesis of empirical evidence of food security and mitigation benefits from improved cropland management. Mitigation of Climate Change in Agriculture Series, $3,1-42$.

Dunnett, A., \& P. B. Shirsath. (2013). New toolkit on climate-smart agriculture can help policymakers make better decisions. The Consultative Group for International Agricultural Research's (CGIAR) Research Program on Climate Change, Agriculture, and Food Security (CCAFS), Copenhagen, Denmark.

Food and Agriculture Organization, (2010). Climate-smart agriculture: Policies, practices and financing for food security, adaptation and mitigation. Food and Agriculture Organization of the United Nations (FAO).

Food and Agriculture Organization, (2014) Climate-smart agriculture: Managing ecosystems for sustainable livelihood. Food and Agriculture Organization of the United Nations (FAO). 
Franzel, S., Kiptot, E., \& Degrande, A. (2019). Farmer-to-farmer extension: A low-cost approach for promoting Climate-smart agriculture. In T.S. Rosenstock, A. Nowak, A., \& E. Girvetz (Eds.), The Climate-Smart Agriculture Papers (pp. 277-288). Rosenstock, Springer Open.

Imran, M. A., Ali, A., Ashfaq, M., Hassan, S., Culas, R., \& Ma, C. (2018). Impact of Climate-smart agriculture (CSA) practices on cotton production and livelihood of farmers in Punjab, Pakistan. Sustainability, 10(6), 2101.

Jellason, N. P., Conway, J. S., \& Baines, R. N. (2021). Understanding impacts and barriers to adoption of climate-smart agriculture (CSA) practices in North-Western Nigerian drylands. The Journal of Agricultural Education and Extension, 27(1), 55-72.

Khatri-Chhetri, A., Aggarwal, P. K., Joshi, P. K., \& Vyas, S. (2017). Farmers' prioritization of Climate-smart agriculture (CSA) technologies. Agricultural System, 151, 184-191.

Koji, A. S. A. I. (2016). Questionnaire survey on farming adaptation for climate variability in Serang Municipality, Indonesia. Memoirs of the Faculty of Engineering, Yamaguchi University, 67(2), 99-106.

Kpadonou, R. A. B., Owiyo, T., Barbier, B., Denton, F., Rutabingwa, F., \& Kiema, A. (2017). Advancing climate-smart agriculture in developing drylands: Joint analysis of the adoption of multiple onfarm soil and water conservation technologies in West African Sahel. Land Use Policy, 61, 196-207.

Kurukulasuriya, P., \& Ajwad, M.I. (2007). Application of the Ricardian technique to estimate the impact of climate change on smallholder farming in Sri Lanka. Climatic Change, 81(1), 39-59.

Lipper, L., Thornton, P., Campbell, B. M., Baedeker, T., Braimoh, A., Bwalya, M., Caron, P., Cattaneo, A., Garrity, D., Henry, K., \& Hottle, R. (2014). Climate-smart agriculture for food security. Nature Climate Change, 4(12), 1068-1072.

Long, T. B., Blok, V., \& Coninx, I. (2016). Barriers to the adoption and diffusion of technological innovations for climate-smart agriculture in Europe: Evidence from the Netherlands, France, Switzerland and Italy. Journal of Cleaner Production, 112, 9-21. 
Lopez-Ridaura, S., Frelat, R., Wijk, M. T. V., Valbuena, D., Krupnik, T. J., \& Jat, M. L. (2018). Climate-smart agriculture, farm household typologies and food security: An ex-ante assessment from Eastern India. Agricultural Systems, 159, 57-68.

Marambe, B., Silva, P., Weerahewa, J., Pushpakumara, G., Punyawardena, R., \& Pallawala, R. (2015). Enabling policies for agricultural adaptations to climate change in Sri Lanka. In W. L. Filho (Ed.), Handbook of Climate Change Adaptation (pp. 901927). Springer.

McCarthy, N., Lipper, L., \& Branca, G. (2011, October). Climate-smart agriculture: Smallholder adoption and implications for climate change adaptation and mitigation [Working paper]. Food and Agriculture Organization of the United Nations.

Middelberg, S. L. (2013). Sustainable agriculture: A review of challenges facing the South African agricultural sector. Journal of Human Ecology, 42(2), 163-169.

Morton, J. F. (2007). The impact of climate change on smallholder and subsistence agriculture. Proceedings of the National Academy of Sciences, 104(50), 19680-19685.

Mwongera, C., Shikuku, K.M., Twyman, J., Läderach, P., Ampaire, E., Asten, P. V., \& Winowiecki, L. A. (2017). Climate-smart agriculture rapid appraisal (CSA-RA): A tool for prioritizing context-specific climate-smart agriculture technologies. Agricultural System, 151, 192-203.

Neufeldt, H., Jahn, M., Campbell, B. M., Beddington, J. R., Declerck, F., De Pinto, A., \& Lezaks, D. (2013). Beyond climate-smart agriculture: Toward safe operating spaces for global food systems. Agriculture \& Food Security, 12(2), 1-6.

Nyasimi, M., Kimeli, P., Sayula, G., Radeny, M., Kinyangi, J., \& Mungai, C. (2017). Adoption and dissemination pathways for climate-smart agriculture technologies and practices for climateresilient livelihoods in Lushoto, Northeast Tanzania. Climate, 5(3), 63. 
Pagliacci, F., Defrancesco, E., Mozzato, D., Bortolini, L., Pezzuolo, A., Pirotti, F., Pisani, E., \& Gatto, P. (2020). Drivers of farmers' adoption and continuation of climate-smart agricultural practices. A study from northeastern Italy. Science of the Total Environment, 710, 1-13.

Papke, L. E., \& Wooldridge, J. M. (1996). Econometric methods for fractional response variables with an application to $401(\mathrm{k})$ plan participation rates. Journal of Applied Econometrics, 11(6), 619632.

Prasannath, V. (2015). Trends and developments in Sri Lanka's livestock industry. Journal for Studies in Management and Planning, 1(4), 46-55.

Qui, C. (2016). Smallholder farmer perceptions on the climate smart agriculture (CSA) practices in eastern India, Bihar. Netherlands, Farming System Ecology Group.

Sain, G., María, A., Corner-dolloff, C., Lizarazo, M., Nowak, A., Martínez-barón, D., \& Andrieu, N. (2017). Costs and benefits of climate-smart agriculture: The case of the dry corridor in Guatemala. Agricultural Systems, 151, 163-173.

Sapkota, T. B., Jat, M. L., Aryal, J. P., Jat, R. K., \& Khatri-Chhetri, A. (2015). Climate change adaptation, greenhouse gas mitigation and economic profitability of conservation agriculture: Some examples from cereal systems of Indo-Gangetic Plains. Journal of Integrative Agriculture, 14(8), 1524-1533.

Sapkota, T. B., Majumdar, K., Jat, M. L., Kumar, A., Bishnoi, D. K., Mcdonald, A. J., \& Pampolino, M. (2014). Precision nutrient management in conservation agriculture based wheat production of Northwest India: Profitability, nutrient use efficiency and environmental footprint. Field Crop Research, 155, 233-244.

Sarker, M. N. I., Wu, M., Alam, G. M., \& Islam, M. S. (2019). Role of climate-smart agriculture in promoting sustainable agriculture: A systematic literature review. International Journal of Agricultural Resources, Governance and Ecology, 15(4), 323-337. 
Senaratne, A., \& Scarborough, H. (2011, February 8-11). Coping with climatic variability by rain-fed farmers in dry zone, Sri Lanka: Towards understanding adaptation to climate change. $55^{\text {th }}$ Annual National Conference of the Australian Agricultural and Resource Economics Society (AARES), Melbourne, Australia.

Seo, S. N. N., Mendelsohn, R., \& Munasinghe, M. (2005). Climate change and agriculture in Sri Lanka: A Ricardian valuation. Environment and Development Economics, 10(5), 581-596.

Sheinkman, M., McKinley, J., Adaro, C., Bandyopadhyay, S., \& Panda, A. (2015). Climate-smart agriculture (CSA) technologies in Asia CCAFS [Workshop Report]. CGIAR Research Program on Climate Change, Agriculture and Food Security (CCAFS). Copenhagen, Denmark.

Steenwerth, K. L., Hodson, A. K., Bloom, A. J., Carter, M. R., Cattaneo, A., Chartres, C. J., \& Jackson, L. E. (2014). Climate-smart agriculture global research agenda: Scientific basis for action. Agriculture and Food Security, 11(3), 1-39.

Thadshayini, V., Nianthi, K. R., \& Ginigaddara, G. A. S. (2020). Climate-smart and resilient agricultural practices in Eastern Dry Zone of Sri Lanka. Global Climate Change: Resilient and Smart Agriculture (pp. 33-68). Springer.

Truelove, H. B., Carrico, A. R., \& Thabrew, L. (2015). A sociopsychological model for analyzing climate change adaptation: A case study of Sri Lankan paddy farmers. Global Environmental Change, 31, 85-97.

Tong, Q., Swallow, B., Zhang, L., \& Zhang, J. (2019). The roles of risk aversion and climate-smart agriculture in climate risk management: Evidence from rice production in the Jianghan Plain, China. Climate Risk Management, 26, 100199.

United Nations Development Programme. (2007). Fighting climate change: Human solidarity in a divided world. Human Development Report 2007/08. Macmillan. 
Verchot, L. V., Van Noordwijk, M., Kandji, S., Tomich, T., Ong, C., Albrecht, A., Mackensen, J., Bantilan, C., Anupama, K. V., \& Palm, C. (2007). Climate change: Linking adaptation and mitigation through agroforestry. Mitigation and Adaptation Strategies for Global Change, 12(5), 901-918.

Wekesa, B. M., Ayuya, O. I., \& Lagat, J. K. (2018). Effect of climatesmart agricultural practices on household food security in smallholder production systems: Micro-level evidence from Kenya. Agriculture \& Food Security, 7(1), 1-14.

Wickremasinghe, S. I. (2006). Development of the national agricultural research system (NARS) in Sri Lanka with special reference to food crops sub-sector: Issues related to science policy. Journal of Natural Science Foundation Sri Lanka, 34(2), 69-83.

World Bank CIAT. (2015). Climate-smart agriculture in Sri Lanka. CSA Country Profiles for Africa, Asia, and Latin America and the Caribbean Series. The World Bank Group. 